\title{
Dermatopathy Caused by Enterobacter aerogenes and Pseudomonas aeruginosa in Boa constrictor amarali
}

\author{
Nathana Beatriz Martins', Lucas Arthur Ricardo Ferreira', André Luiz Quagliatto Santos', Rafael Rocha de Souza ${ }^{2}$, \\ Wilson Junior Oliveira ${ }^{2}$, Thaís de Almeida Moreira ${ }^{3}$, Caroline Lopes Queiroz ${ }^{4}$ \& Anna Monteiro Correia Lima ${ }^{4}$
}

\begin{abstract}
Background: Bacterial diseases are the main cause of the high mortality rates of snakes, especially those caused by gramnegative agents. However, studies on dermatopathy caused by these bacterial agents in snakes are scarce; and no reports have been found on Enterobacter aerogenes as causative agent of dermatopathy in snake species. Thus, the objective of this study was to describe the clinical signs, and lesion evolution of a dermatopathy in a male snake (Boa constrictor amarali) specimen of approximately seven years old; and to describe the isolation and identification of the Enterobacter aerogenes and Pseudomonas aeruginosa agents involved in the cause of this disease.

Case: The Boa constrictor amarali evaluated presented blackened cutaneous lesions in the dorsal, snout-vent and tail regions; and well-defined subcutaneous nodules of 2.0-3.0 cm diameter, with soft consistency, reddish color, cutaneous flaccidity, and areas of scale ulceration in the dorsolateral region. The clinical evaluation of the animal showed dehydration signs and pale mucous membranes. The blackened lesions were subjected to mycological analysis - after procedure of deep scale scraping - which showed presence of septate hyphae. The nodule was punctured for microbiological and biochemical analysis. The sample was collected with a sterilized alginate cotton tip swab, and was stored in a plastic tube containing a semi-solid Stuart transport medium, for microbiological analysis. Then, this sample was incubated in a bacteriological oven at $37^{\circ} \mathrm{C}$ for $24 \mathrm{~h}$. Typical colonies of Pseudomonas and Enterobacter grew on MacConkey agar medium; these bacteria were identified by the colony morphology and their typical odor. The colonies grown in MacConkey agar were also identified through biochemical tests in the mediums: Phenol red, Lysine, Phenylalanine, Citrate, Urea and SIM (Sulfide, Indole, Motility). The results of these tests were able to confirm and identify the $P$. aeruginosa and E. aerogenes species. The animal died within $36 \mathrm{~h}$, before the identification of the causative agents of the disease, thus, no pharmacological interference was possible.

Discussion: Immunodepression, malnutrition, and temperatures and humidity outside the animal thermal comfort zone, are predisposing factors for the development of bacterial diseases in reptiles. Little information about pathogen agents affecting Boa constrictor specimens in their native area is available; however, captive snakes are subject to a wide variety of diseases - most of which caused or intensified by the captivity conditions. Among the bacteria involved in reptile diseases, few are primary causative agents. In general, clinical bacterial infections tend to be secondary to viral infections. The bacterial agents found in this study are commonly described in scientific literature with location in the oral cavity, differently from the results found in this study. Moreover, the bacterium E. aerogenes has not yet been described in other studies as a causative agent of dermatopathy. Reptiles are considered reservoirs of important zoonotic microorganisms, such as $P$. aeruginosa, which can be transmitted by fecal contact, bites and wounds. However, the little information on P. aeruginosa in captive reptiles indicates the need for further studies to establish its zoonotic potential. A most adequate management conditions for the snake species could have decreased the severity of the lesions. The occurrence of $P$. aeruginosa and $E$. aerogenes found in this work may alert professionals for future clinical suspicions and adequate therapeutic management.
\end{abstract}

Keywords: bacterioses, Amaral's boa, snakes. 


\section{INTRODUCTION}

The Boa constrictor amarali is a non-venomous snake of the order Squamata (Ophidia) that is widely distributed in Brazil [6], especially in the Northeast, Southeast and South regions [11].

Among the bacterial diseases that can occur in this species, those caused by gram-negative agents are the most important $[1,5,8]$. However, the scientific literature has very little information on dermatopathy in snakes caused by these bacterial agents, and no reports of Enterobacter aerogenes as causative agent of cutaneous lesions in this species.

Enterobacter spp. and Pseudomonas spp. are bacteria present in the microbiota of snakes, especially in their oral cavities and intestines. However, in conditions of high pathogenicity, these bacteria have already been connected to high morbidity and mortality of infected animals; this occurs due to their capacity to develop resistance to antibiotics, and express multiple virulence factors $[8,9]$. These factors are due to their opportunistic behavior, which causes clinical manifestations in other organs of susceptible reptiles [2,5].

Thus, the objective of this study was to describe the clinical signs and lesion evolution of a dermatopathy in a snake (Boa constrictor amarali) specimen; and to describe the isolation and identification of the Enterobacter aerogenes and Pseudomonas aeruginosa agents involved in the cause of this disease.

\section{CASE}

A wild male specimen of Boa constrictor amarali - also known as Amaral's boa - of approximately 7-year-old, without previous history was rescued in an urban area and taken by the Environmental Police to the Teaching and Research Laboratory of Wild Animals (LAPAS) of the Veterinary Hospital of the Federal University of Uberlândia (UFU), in the state of Minas Gerais, Brazil. In the laboratory, the animal was fed weekly, with live rats - Rattus novergicus - from the vivarium of the university.

The animal was weighed in a digital scale and presented 2,210 kg. Regarding the biometric data, the animal had a head length of $7 \mathrm{~cm}$ (HL), which was measured with a digital caliper; snout-vent length (SVL) of $149 \mathrm{~cm}$; and tail length (TL) of $14 \mathrm{~cm}$. A tape measure was used to obtain the body and tail lengths.

The clinical evaluation showed dehydration signs, and pale aspect of the ocular, oral and genital mucous membranes. The animal presented blackened skin lesions of irregular contour distributed mainly on the dorsal region, and to a lesser extent in the snoutvent and tail regions (Figure 1-A). This evaluation also presented multiple well-defined subcutaneous nodules of 2.0-3.0 cm diameter, with soft consistency, cutaneous flaccidity, and areas of scale ulceration in the dorsolateral area of the cloacal region (Figure 2-A).

Material from the blackened lesions were collected through deep scale scraping for analysis and diagnosis. This material was placed on a microscopy slide, and potassium hydroxide 50\% $\quad\left(\operatorname{Synth}^{\circledR}\right)^{1}$ was added for the sample whitening. Fungi with septate hyphae were observed (Figure 1-B).

The nodules of the dorsolateral area of the cloacal region were punctured, from which a translucent, odorless blood-containing material flowed. This material was collected with a sterilized alginate cotton tip swab and stored in a plastic tube containing a semi-solid Stuart transport medium ${ }^{\circledR 2}$. Then, the sample was transferred to a tube containing Thioglycollate broth medium ${ }^{\circledR 3}$, which is a highly nutritive medium that helps the growth of microorganisms. Subsequently, the sample was incubated in a bacteriological oven at $37^{\circ} \mathrm{C}$ for $24 \mathrm{~h}$.

Samples were plated on Petri dish ${ }^{\circledR 4}$ dishes using platinum inoculating loop for bacterial isolation: one Petri dish containing blood agar, and other containing MacConkey agar ${ }^{\circledR 4}$, using the streaking technique. These dishes were placed in a bacteriological oven at $37^{\circ} \mathrm{C}$ for $24 \mathrm{~h}$ for incubation. Gram staining was used for the identification of the gram-positive and gramnegative bacteria in the blood agar base ${ }^{\circledR 4}$ colonies.

The colonies grown in MacConkey agar were identified through biochemical tests in the mediums: Phenol red Broth Base ${ }^{\circledR 5}$, Lysine $\left(\text { L-Lysine }^{\circledR}\right)^{5}$, Phenylalanine Agar $^{\circledR 5}$, Citrate Agar $^{\circledR 5}$, Urea Agar

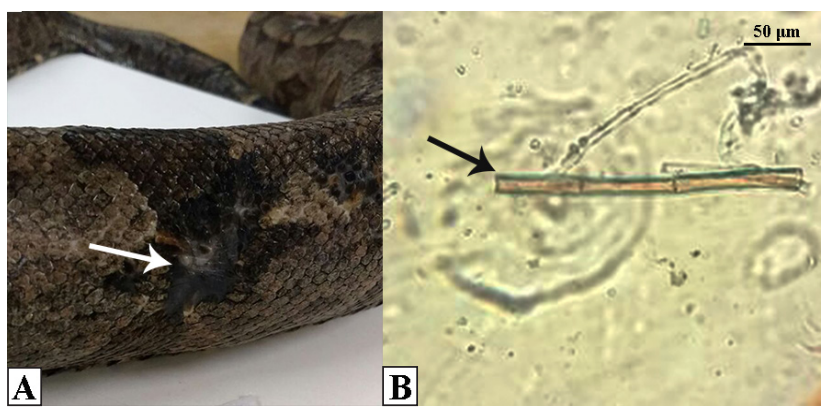

Figure 1. A- Macroscopic aspect of a cutaneous lesion in a Boa constrictor amarali snake. The lesion is located in the dorsal region (arrow), and presents blackish color and irregular contours. B- Fungi with septate hyphae observed in deep scale scrapings. 40x objective. Whitening with potassium hydroxide. 
Base-Christensen ${ }^{\circledR 5}$ and SIM (Sulfide, Indole, Motility - Medium $\left.{ }^{\circledR}\right)^{6}$. These mediums have the purpose of screening colonies that grow on selective medium for gram-negative bacteria from the Enterobacteriaceae family. A medium was used for each different colony grown in the MacConkey agar to identify each bacterial genus or species. Colonies of gram-negative bacteria that were not from the Enterobacteriaceae family were also subjected to the Oxidation-Fermentation test.

Typical colonies of Pseudomonas and Enterobacter grew on MacConkey agar medium; these bacteria were identified by the colony morphology and their typical odor. The biochemical tests were able to confirm and identify the $P$. aeruginosa and $E$. aerogenes species (Figure 2-B).

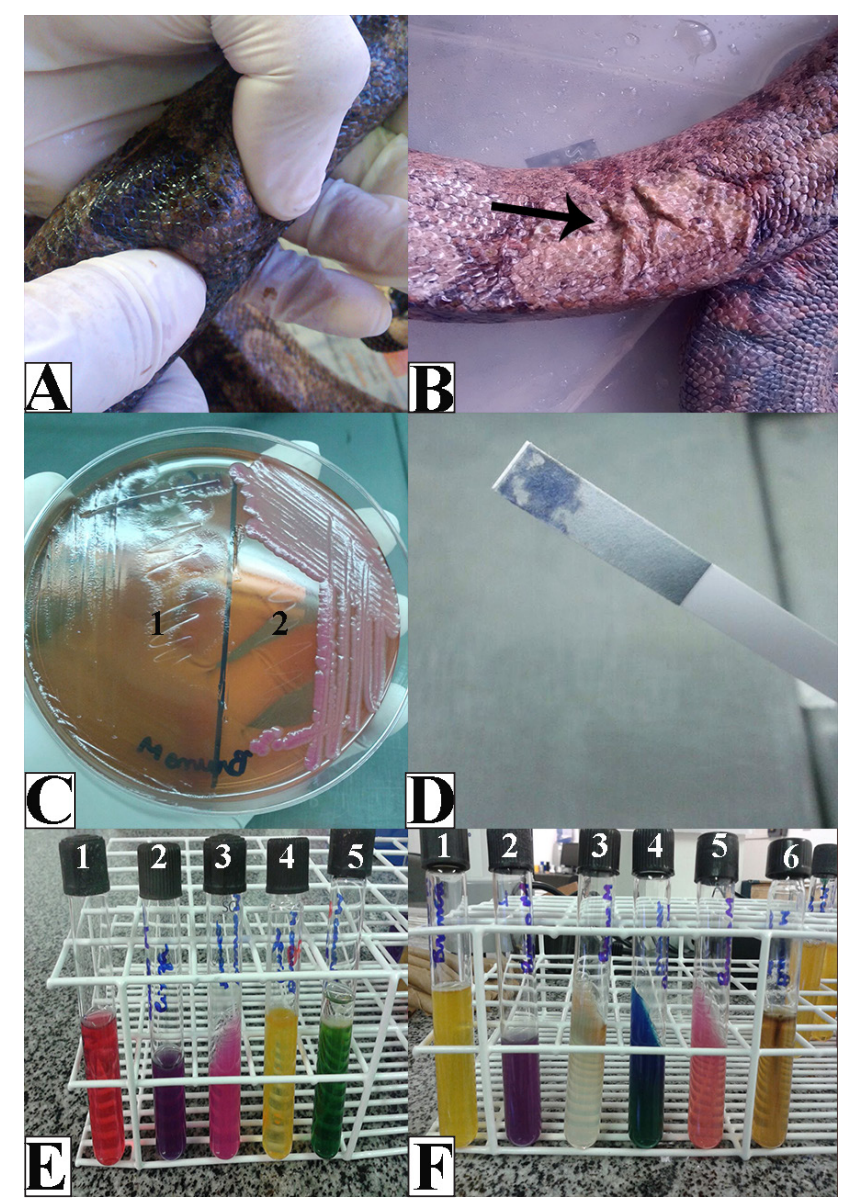

Figure 2. A- Macroscopic aspect of a subcutaneous nodule in a Boa constrictor amarali snake. The nodule has a well-defined regular contour. BArea with cutaneous flaccidity (arrow). C- Bacterial colonies of Pseudomonas aeruginosa (1) and Enterobacter aerogenes (2) grown on MacConkey agar. D- Cytochrome oxidase test confirming the presence of $P$. aeruginosa. EBiochemical tests for confirmation of $P$. aeruginosa: negative Phenol red test (1); arginine dihydrolase positive test (2); positive urease production test (3); positive oxidation test (4); and negative fermentation test (5). FBiochemical tests for confirmation of E. aerogenes: positive Phenol red test (1); positive lysine decarboxylation test (2); negative phenylalanine test (3); positive Simmons citrate test (4); positive urease production test (5); sulfide (negative), indole (negative), motility (positive) test (6).

\section{DISCUSSION}

Wild animals in captive environments may develop the maladaptation syndrome, which is responsible for about $80 \%$ of their deaths. Skin ulceration can be found in points of friction, which increases the susceptibility to infections by pathogenic and opportunistic microorganisms [4,11,13]. Based on the findings of this case, this fact must be taken into account as a possible cause of the fungal and bacterial lesions found in the evaluated animal.

Moreover, filamentous fungi with pathogenic potential on body surface of Boa constrictor snakes are described in scientific literature, mainly in captive animals [4]; and an increase in the number of cases of these cutaneous infections has been reported [7], which confirms the results found in this case.

Few bacteria involved in reptile diseases are primary causative agents, as found in this study. In general, clinical bacterial infections tend to be secondary to viral infections $[10,13]$. In addition, the bacterial agents found in the present study are commonly reported as belonging to the microbiota of snakes, especially in the oral cavity and intestines $[8,9]$. However, under conditions of high pathogenicity, they may develop clinical manifestations in other organs $[2,14]$, as found in this study.

$P$. aeruginosa has been described as a causative pathogen of generalized cutaneous nodules in Micrurus corallines snakes [1,12]. However, the scientific literature has not yet reported the E. aerogenes as a causative agent of skin lesions, as found in this study. Information on E. aerogenes are frequently connected to oral and intestinal diseases [5].

Reptiles are considered reservoirs of important zoonotic microorganisms, such as $P$. aeruginosa, which can be transmitted by fecal contact, bites and wounds $[3,6,13,14]$. However, the limited information available on these infections in captive reptiles indicates the need for further studies to establish their zoonotic potential.

This study found the bacteria $P$. aeruginosa and $E$. aerogenes as responsible for producing nodular lesions in a Boa constrictor snake. This result indicates the possibility that the concomitant infection may have intensified the clinical condition of the animal, causing its death. Thus, the control of zoonotic agents through adequate sanitary and environmental management is important; because these agents are 
commonly isolated in this species, and when immune system depression occurs, their effects are intensified and cause various clinical symptoms, such as dermatopathy.

\section{MANUFACTURERS}

${ }^{1}$ SP Labor Comércio de Produtos para Laboratório Ltda. Presidente Prudente, SP, Brazil.

${ }^{2}$ Citotest Labware Manufacturing Co. Ltda. Jiangsu, China.
${ }^{3}$ Sigma Aldrich Brasil Ltda. São Paulo, SP, Brazil.

${ }^{4}$ Kasvi Importação e Distribuição de Produtos para Laboratórios Ltda. Pinhais, PR, Brazil.

${ }^{5}$ HiMedia Laboratories Pvt. Ltda. Mumbai, India.

${ }^{6}$ Merck KGAA. Darmstadt, Germany.

Declaration of interest. The authors report no conflicts of interest. The authors alone are responsible for the content and writing of the paper.

\section{REFERENCES}

1 Colinon C., Jocktane D., Brothier E., Rossolini G. M., Cournoyer B. \& Nazaret S. 2010. Genetic analyses of Pseudomonas aeruginosa isolated from healthy captive snakes: evidence of high inter-and intrasite dissemination and occurrence of antibiotic resistance genes. Environmental microbiology. 12(3): 716-729.

2 Cushing A., Pinborough M. \& Stanford M. 2011. Review of bacterial and fungal culture and sensitivity results from reptilian samples submitted to a UK laboratory. Veterinary Record. 69(15): 390.

3 Foti M., Giacopello C., Fisichella V. \& Latella G. 2013. Multidrug-resistant Pseudomonas aeruginosa isolates from captive reptiles. Journal of Exotic Pet Medicine. 22(3): 270-274.

4 Freire B.C., Garcia V.C., Lucas M.S.B., Cardoso S.R.T., Puorto G. \& Bentubo H.D.L. 2015. Pesquisa de fungos filamentosos de potencial patogênico para serpentes constritoras da família Boidae mantidas em cativeiro no Museu Biológico do Instituto Butantan, São Paulo, SP. Revista de Educação Continuada em Medicina Veterinária e Zootecnia. 13(2): 45-46.

5 Jacobson E.R. 2007. Bacterial diseases of reptiles. In: Infectious diseases and pathology of reptiles: color atlas and text. Boca Raton: CRC Press, pp.461-562.

6 Kolesnikovas C.K.M., Greco K.F. \& Rahme-de-Albuquerque L.C. 2006. Répteis - Ordem Squamata - Subordem Ophidia. In: Cubas Z.S., Silva J.C.R. \& Catão Dias J.L. (Eds). Tratado de animais selvagens - Medicina veterinária. São Paulo: Roca Ltda., pp.68-85.

7 Lorch J.M., Knowles S., Lankton J.S., Michell K., Edwards J.L., Kapfer J.M., Staffen R.A., Wild E.R., Schmidt K.Z., Ballmann A.E., Blodgett D., Farrell T.M., Glorioso B.M., Last L.A., Price S.J., Schuler K.L., Smith C.E., Wellehan Jr. J.F.X. \& Blehert D.S. 2016. Snake fungal disease: an emerging threat to wild snakes. Philosophical Transactions of the Royal Society B. 5(371): 1709.

8 Ortiz-Suarez F.I., Ortegon-Cardenas L.H., Ortega-Bolaños Y.L. \&Toledo-Brausi L.A. 2016. Identificación de la flora bacteriana associada a la cavidad oral en ejemplares cautivos de cascabel suramericana (Crotalus durissus). Fagropec. 8(1): 25-29.

9 Palamthodi S.M., Gaikwad V.J., Ghasghase N.V. \& Patil S.S. 2011. Antibacterial targets in Pseudomonas aeruginosa. International Journal of Pharmaceutics Applications. 2(3): 159-164.

10 Pasmans F., Blahak S., Martel A. \& Pantchev N. 2008. Introducing reptiles into a captive collection: the role of the veterinarian. The Veterinary Journal. 175(1): 53-68.

11 Reed R.N. \& Rodda G.H. 2009. Giant constrictors: biological and management profiles and an establishment risk assessment for nine large species of pythons, anacondas, and the Boa constrictor. US Geological Survey, Reston, Virginia, pp.142-186. [Fonte: < https://pubs.usgs.gov/of/2009/1202/pdf/OF09-1202.pdf>]. [Acessed online in July 2016].

12 Serapicos D.O.E., Casagrande R.A., Matushima E.R. \& Merusse J.L.B. 2005. Macro and microscopic alterations observed in coral snakes Micrurus corallinus in laboratory animal rooms (Reptilia-Ophidia-Elapidae). Revista Portuguesa de Ciências Veterinárias. 100(553-554): 71-74.

13Stenglein M.D., Guzman D.S.M., Garcia V.E., Layton M.L., Hoon-Hanks L.L., Boback S.M., Keel M.K., Drazenovich T., Hawkins M.G. \& DeRisi J.L. 2017. Differential disease susceptibility in experimentally reptarenavirus infected boa constrictors and ball pythons. Journal of Virology. 91(15): 1-28. JVI-00451.

14 Wernick M.B.; Novo-Matos J., Ebling A., Kuhn K., Ruetten M., Hilbe M., Howard J., Chang R., Prohaska S. \& Hatt J.M. 2015. Valvulopathy consistent with endocarditis in an argentine boa (Boa constrictor occidentalis). Journal of Zoo and Wildife Medicine. 46(1): 124-129.

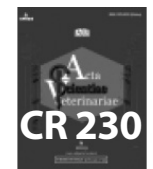

